\title{
Pension fund's illiquid assets allocation under liquidity and capital requirements
}

Citation for published version (APA):

Broeders, D., Jansen, K. A. E., \& Werker, B. J. M. (2021). Pension fund's illiquid assets allocation under liquidity and capital requirements. Journal of Pension Economics \& Finance, 20(1), 102-124. [1474747219000398]. https://doi.org/10.1017/S1474747219000398

Document status and date:

Published: 01/01/2021

DOI:

10.1017/S1474747219000398

Document Version:

Publisher's PDF, also known as Version of record

Document license:

Taverne

Please check the document version of this publication:

- A submitted manuscript is the version of the article upon submission and before peer-review. There can be important differences between the submitted version and the official published version of record.

People interested in the research are advised to contact the author for the final version of the publication, or visit the DOI to the publisher's website.

- The final author version and the galley proof are versions of the publication after peer review.

- The final published version features the final layout of the paper including the volume, issue and page numbers.

Link to publication

\footnotetext{
General rights rights.

- You may freely distribute the URL identifying the publication in the public portal. please follow below link for the End User Agreement:

www.umlib.nl/taverne-license

Take down policy

If you believe that this document breaches copyright please contact us at:

repository@maastrichtuniversity.nl

providing details and we will investigate your claim.
}

Copyright and moral rights for the publications made accessible in the public portal are retained by the authors and/or other copyright owners and it is a condition of accessing publications that users recognise and abide by the legal requirements associated with these

- Users may download and print one copy of any publication from the public portal for the purpose of private study or research.

- You may not further distribute the material or use it for any profit-making activity or commercial gain

If the publication is distributed under the terms of Article $25 \mathrm{fa}$ of the Dutch Copyright Act, indicated by the "Taverne" license above, 


\title{
Pension fund's illiquid assets allocation under liquidity and capital requirements
}

\author{
Dirk W. G. A. Broeders ${ }^{1 *}$, Kristy A. E. Jansen² and Bas J. M. Werker ${ }^{3}$ \\ ${ }^{1}$ Maastricht University and De Nederlandsche Bank, Amsterdam, Netherlands, ${ }^{2}$ Tilburg University and De Nederlandsche \\ Bank, Tilburg, Netherlands and ${ }^{3}$ Tilburg University, Tilburg, Netherlands \\ ${ }^{\star}$ Corresponding author. Email: d.w.g.a.broeders@dnb.nl
}

(Received 9 September 2019; revised 18 November 2019; accepted 18 November 2019; first published online 7 January 2020)

\begin{abstract}
Defined benefit pension funds invest in illiquid asset classes for return, diversification or liability hedging reasons. So far, little is known about factors influencing how much they invest in illiquid assets. We conjecture that liquidity and capital requirements are pivotal in this decision. Short-term pension payments and margining on derivative contracts generate liquidity requirements, while regulations impose capital requirements. Consistent with our model we empirically find that these requirements create a humpshaped impact of liability duration on the fraction of risky assets invested in illiquid assets. Further, we report that pension fund size, type, and funding ratio impact illiquid assets allocations.
\end{abstract}

Key words: Asset allocation; asset liability management; capital requirements; illiquid assets; liquidity requirements; pension funds

JEL Codes: G11; G23

\section{Introduction}

Pension funds are important investors in illiquid asset classes such as real estate, mortgages, private equity, hedge funds, and infrastructure. The annual OECD survey of large pension funds reveals an average illiquid assets allocation of $15 \%$ in 34 countries. ${ }^{1}$ According to the 2018 Willis Towers Watson Global Pension Asset Study, the seven largest pension markets in the world (Australia, Canada, Japan, the Netherlands, Switzerland, UK, and USA) have increased their average illiquid assets allocation from $4 \%$ in 1997 to $25 \%$ in $2017 .^{2}$ Illiquid assets may offer pension plans benefits in terms of a liquidity premium e.g., Sadka (2010), Franzoni et al. (2012), and Qian and Liu (2012), portfolio diversification (Jacobs et al., 2014), and liability hedging (Hoevenaars et al., 2008). Their long investment horizon makes pension funds well placed to invest in illiquid asset classes (Attig et al., 2012).

Several papers study investment risk-taking by pension funds, e.g., Sharpe (1976), Jin et al. (2006), Rauh (2009), An et al. (2013), and Andonov et al. (2017). These papers typically focus on the allocation to risk-free assets (such as government bonds) on the one hand versus risky assets (such as equities) on the other hand. In this paper, we address the investment policy of pension funds regarding illiquid asset classes. So far, little is known about the factors that influence how much they invest in illiquid asset classes. The main purpose of this paper is to show how liquidity and capital requirements affect the appetite of pension funds towards investing in illiquid assets. Several papers provide indeed evidence that regulations have a significant impact on pension fund's investment decisions, e.g.,

\footnotetext{
${ }^{1}$ www.oecd.org/daf/fin/private-pensions/2015-Large-Pension-Funds-Survey.pdf

${ }^{2}$ https://www.willistowerswatson.com/-/.../Global-Pension-Asset-Study-2018-Japan.pdf

(c) Cambridge University Press 2020. This is an Open Access article, distributed under the terms of the Creative Commons Attribution licence (http://creativecommons.org/licenses/by/4.0/), which permits unrestricted re-use, distribution, and reproduction in any medium, provided the original work is properly cited.
} 
Sias (2004), An et al. (2013), and Andonov et al. (2017). We, therefore, build our paper on a theoretical model of liquidity and capital requirements. Based on that model we link pension funds' characteristics to their investments in illiquid assets. We test this in an empirical study using unique and unbiased data on Dutch pension funds.

First, we assess the aggregate illiquid assets allocation as a fraction of the risky assets allocation, following the typical top-down decision-making process of a pension fund. Second, we study the implications for the following illiquid asset classes separately: real estate, mortgages, private equity, and hedge funds. While we do the empirical analysis on defined benefit pension plans in this paper, our theoretical framework also applies to different types of institutional investors. For instance, insurers with guaranteed products take into account both liquidity and capital requirements in choosing their optimal asset allocation (Niedrig, 2015). Also, banks are exposed to liquidity and capital requirements in their asset allocation decision (Khan et al., 2017).

The liquidity requirements of pension funds consist of two components: short-term pension payments and collateral requirements following margin calls on derivative contracts. The cash required for pension payments over the next year is well predictable. However, the cash needed for collateral requirements is much less predictable. If the market value of a derivative contract declines, a pension fund must transfer cash or highly liquid short-term bonds to a margin account in order to limit the risk the counterparty faces. Margining on derivatives can become quite substantial, especially during financial crises.

We also consider capital requirements as a source of variation in illiquid assets holdings by pension funds. Regulations often require defined benefit plans to have sufficient capital to manage the risks they are exposed to, such as financial market risks and longevity risk. ${ }^{3}$ In choosing its strategic asset allocation, a pension fund optimizes the trade-offs between different risk factors for a given level of required capital. As a result, a pension fund may be constrained to increase their exposure to illiquid assets. If a certain risk factor consumes a larger part of the available capital, less capital remains to be allocated to illiquid assets.

Liquidity and capital requirements interact in two ways. First, they interact through the liability duration as a measure of a pension fund's average investment horizon. On the one hand, a pension fund with a high liability duration is less liquidity constrained as it will have to pay less pensions in the short-term. This allows for a higher allocation to illiquid assets. On the other hand, a high liability duration also implies more exposure to interest rate risk through the present value of its liabilities. This restricts the opportunity to invest in illiquid assets as more of the available capital is required for interest rate risk. Two, liquidity and capital requirements also interact through derivatives. For instance, hedging interest rate risk increases the liquidity requirement as a result of higher collateral requirements. However, by hedging interest rate risk, a pension fund frees up capital to invest more in illiquid assets. Our theoretical model in Section 2 precisely disentangles these effects.

We empirically test the predictions from our theoretical model using the investment decisions of Dutch occupational pension funds from 2012 to 2017. The Dutch pension system is particularly well suited to study the effect of liquidity and capital requirements on the illiquid assets allocation for multiple reasons. First, Dutch pension funds have mandatory reporting requirements to the prudential supervisor, De Nederlandsche Bank (DNB). This gives us unbiased data. Second, the Dutch pension system is large in terms of size. The total assets under management (AUM) of Dutch pension funds' is approximately 1.3 trillion euro or 1.5 times the GDP of the Netherlands. Third, Dutch pension funds do not face quantitative investment restrictions. The regulation allows them to invest in any asset class in any country, as long as a pension fund complies with the capital requirements and the well-known prudent person principle. Dutch pension funds invest in a broad range of asset classes. In fact, over two-thirds of them invest in illiquid assets. Fourth, Dutch pension funds mainly have defined benefit pension liabilities. This means that they have a clear asset-liability perspective in making

\footnotetext{
${ }^{3}$ In Section 2.2 we explain that a pension fund's capital is the difference between the market value of assets and liabilities. The term capital requirements is synonymous to funding requirements.
} 
strategic investment decisions. Liabilities are valued marked-to-market by discounting accrued benefits against the prevailing term structure of market interest rates. As a result, we can analyze the impact of liability interest rate risk on the illiquid assets allocation.

In short, these are our key findings. First, in line with our theoretical framework, we find a humpshaped impact of liability duration on the fraction of risky assets invested in illiquid assets. Up to 18 years, liability duration positively affects this allocation. For higher durations, the effect reverses. Second, we do not find evidence that interest rate risk hedging impacts the fraction of risky assets allocated to illiquid assets. Currency risk hedging, by contrast, creates the opportunity to allocate more to illiquid assets. A one standard deviation increase in currency risk hedging leads to an increase in the fraction of risky assets allocated to illiquid assets of approximately 0.71 percentage points. This implies a relative increase in the fraction of risky assets allocated to illiquid assets of 5.5\%. Third, we find that, next to liability duration, also other pension fund characteristics impact strategic asset allocation decisions. Size positively affects the fraction of risky assets allocated to illiquid assets, which is in line with Andonov (2014) and Dyck and Pomorski (2016). A pension fund that is ten times larger in terms of AUM has a 7.4 percentage points higher fraction of risky assets allocated to illiquid assets. Furthermore, corporate pension funds invest 7.6 percentage points less in illiquid assets as a fraction of risky assets compared to industry-wide and professional group pension funds. Finally, pension funds with a lower funding ratio invest a larger fraction of risky assets in illiquid assets, supporting the results found in Basak and Shapiro (2001). A one standard deviation decrease in the funding ratio increases the fraction of risky assets allocated to illiquid assets by 0.89 percentage points.

The remainder of this paper is organized as follows. Section 2 explains the liquidity and capital requirements of pension funds and in which way these requirements affect the illiquid assets allocation in a theoretical framework. The data description is given in Section 3. The model and results are discussed in Section 4. The robustness check is in Section 5. Section 6 describes the implications of our theoretical framework for pension funds in different regulatory frameworks and Section 7 concludes.

\section{Illiquid assets allocation: theory}

A key responsibility of a pension fund is to optimize the asset allocation given its liability structure. This is known as asset liability management (ALM). Here, we focus on a specific part of the ALM process: the strategic allocation to illiquid assets. For our theoretical framework, the focus is on the aggregate illiquid assets allocation. In the empirical section we, however, also consider individual illiquid asset classes.

In deriving their strategic allocation to illiquid asset classes, pension funds assess the benefits and costs imposed by these investments. Important drivers of the investment decision are the risk-return trade-offs, the portfolio diversification benefits, and the ability of illiquid assets to hedge liability risk. Other drivers of investment decisions are constraints. We focus on liquidity and capital requirements and conjecture that these impact investment decisions. We therefore first formally introduce liquidity and capital requirements. Next, we show in a theoretical model how the two requirements interact and affect investment decisions.

\subsection{Liquidity requirements}

A pension fund must have sufficient liquidity available to fulfill its immediate obligations. Liquidity requirements consist mainly of two components: short-term pension payments and collateral requirements on the interest rate and currency derivatives. The cash required for pension payments in the foreseeable future is generally well predictable. The number of retirees and their benefits is known. However, the cash needed for collateral requirements is much less predictable. If the market value of a derivative declines, the pension fund is required to transfer cash or highly liquid short-term bonds to a margin account. Margining on derivatives can become quite substantial, especially during financial crises. Pension payments can be seen as the expected liquidity requirement, whereas collateral 
requirements present liquidity risk. Liquidity problems arise when a pension fund lacks the resources to fulfill its immediate obligations. ${ }^{4}$

An investor facing liquidity risk should reduce the allocation to illiquid assets in order to avoid states of the world in which it would be short liquidity. For instance, theoretical studies from Gârleanu (2009) and Ang et al. (2014) show this formally. From a theoretical perspective we, therefore, predict that higher liquidity requirements restrict investments in illiquid assets. We will now discuss liquidity requirements in more detail.

\subsubsection{Liquidity requirement for pension payments}

We start with the short-term pension payments and denote these by $L R_{P}$. We define this as the ratio of pension payments in the first year to the present value of total liabilities. To formalise this, suppose we have a homogeneous group of participants with a mortality rate $\lambda$ that receive annual pension payments of $A$ at the beginning of each year. The pension payments in year $t$ are then given by

$$
A \exp (-\lambda t)
$$

Assuming a flat term-structure of interest rates $r$, the present value of all future pension payments equals

$$
V=\int_{0}^{\infty} A \exp (-(r+\lambda) t) d t=\frac{A}{r+\lambda} .
$$

Then, in relative terms, the short-term pension payments equal

$$
L R_{P}=\frac{A}{A(r+\lambda)^{-1}}=r+\lambda \text {. }
$$

The duration of the present value of future pension payments $V$ equals

$$
D_{V}=-\frac{1}{V} \frac{\mathrm{d} V}{\mathrm{~d} r}=\frac{1}{r+\lambda} \text {. }
$$

Using (3) and (4) we rewrite the liquidity requirement from pension payments as

$$
L R_{P}=\frac{1}{D_{V}} .
$$

Equation (5) has an intuitive interpretation. The liability duration is the weighted average time to maturity of all pension payments. In other words, it measures a pension fund's average investment horizon. A high liability duration $D_{V}$ implies less short-term payments as only a small fraction of the liabilities has to be paid out in the near future. In line with the findings in Ang et al. (2014), a high liability duration, therefore, creates opportunities to invest in illiquid assets. The inability to frequently trade illiquid assets is less of a restriction for a pension fund with a high liability duration.

\subsubsection{Liquidity requirement for interest rate derivatives}

Next to short-term pension payments, liquidity requirements also arise to meet margin requirements on derivatives. We consider margin requirements on interest rate swaps in this section and on

\footnotetext{
${ }^{4}$ Salary payments to pension fund's staff, administrative expenses, and investment costs are also sources that require shortterm liquidity, but are generally small compared to the size of the pension fund and therefore is outside the scope of this paper.
} 
currency forwards in the next section. For model tractability, we refer to the interest rate derivate portfolio as a position in a single receiver swap. Pension funds mainly use receiver swaps to hedge the interest rate risk embedded in the present value of the pension liabilities. In a receiver swap, a pension fund pays a counterparty a floating rate and receives, in return, a fixed rate over a certain notional amount. We denote the notional of the receiver swap by $N$ and the duration of its fixed leg by $D_{R}$. The fraction of interest rate risk hedged with the receiver swap, again relative to the total value of liabilities $V$, is given by the following swap hedge ratio

$$
\phi^{R}=\frac{N}{V} \frac{D_{R}}{D_{V}}
$$

We model the liquidity requirement on the swap through a margin call. In case of a receiver swap, an increase in the interest rate $d r^{+}$leads to a margin call because it lowers the value of the fixed leg of the swap. As a first-order approximation, the margin calls on the swap then equals

$$
M C_{R}=\frac{N D_{R} d r^{+}}{V}=\phi^{R} D_{V} d r^{+}
$$

We could add a second-order, convexity, effect to (6). However, this has only a small effect on the quantitative results of the model and is, therefore, excluded here to keep the model simple.

\subsubsection{Liquidity requirement for foreign exchange derivatives}

The liquidity requirement on foreign exchange derivatives also results from margin calls in case the value of the derivative portfolio decreases. Pension funds generally hedge exchange rate risk using currency forwards. We assume that the pension funds in our model each have a position in a single forward contract. We consider an increase in the foreign exchange rate $d F X^{+}$because this lowers the value of the forward contract and, thus, results in a margin call. The liquidity requirement from margin calls on foreign exchange derivatives then equals

$$
M C_{F X}=w^{F X} \phi^{F X} d F X^{+},
$$

where $w^{F X}$ is the fraction of $V$ invested in foreign assets and $\phi^{F X}$ is the foreign exchange hedge ratio relative to $V$.

We can now determine the total liquidity requirement by adding together (5)-(7). This gives us the total liquidity requirement $L R$, relative to the value of the pension liabilities $V$, as

$$
L R=\frac{1}{D_{V}}+\phi^{R} D_{V} d r^{+}+w^{F X} \phi^{F X} d F X^{+} .
$$

\subsection{Capital requirements}

Next to liquidity requirements the pension funds in our sample also face capital requirements to be able to absorb financial markets risks and longevity risk. In contrast to a bank or an insurer, a pension fund generally does not have shareholders that provide capital. Instead, a pension fund's capital is the difference between the value of the assets and the value of the liabilities. In the Netherlands, the capital requirement is risk-based and calculated as a Value-at-Risk risk measure (Broeders and Pröpper, 2010). In fact, the level of the required capital is calculated such that the probability that the funding ratio falls below $100 \%$ on a 1 -year horizon equals $2.5 \%$. This level is pension fund specific. Pension funds determine the capital requirement by applying a method prescribed by law that takes the following risk factors into account: interest rate risk, equity and real estate risk, currency risk, commodity risk, credit risk, and longevity risk. The capital required for each of these risk factors is determined 
by simulating the impact on a pension fund's capital of a prescribed shock in the risk factor. The total capital requirement follows from aggregating the individual requirements using a correlation matrix. In practice, a pension fund does not always have sufficient capital. If that is the case a pension fund gets a 10-year recovery period to become compliant again. The Dutch setting is unique and allows us to study the effect of capital requirements on the illiquid assets allocation. For the purpose of our paper, we only consider the capital requirement for interest rate risk and for currency risk. Pension funds also have a capital requirement for equity risk. But this requirement is only related to the equity allocation and does not depend on the liability structure, which is the core risk driver in our model.

\subsubsection{Capital requirement for interest rate risk}

The root cause of interest rate risk is embedded in the present value of the future pension payments. Pension funds can hedge this liability interest rate risk not only with receiver swaps but also with bonds. In the Dutch regulations, the capital requirement is therefore based on the part of the liability interest rate risk that is not hedged with swaps and bonds. We already introduced the swap hedge ratio $\phi^{R}$. The bond hedge ratio, or the fraction of interest rate risk hedged with bonds, is denoted by $\phi^{B}$. If a pension fund invests fraction $B / V$ in bonds with a duration of $D_{B}$ then $\phi^{B}$ is defined as

$$
\phi^{B}=\frac{B}{V} \frac{D_{B}}{D_{V}}
$$

Next we consider a decrease in the interest rate $d r^{-}$. An interest rate decrease typically lowers the funding ratio because it increases the value of the liabilities more than the value of the swaps and bonds. The first-order approximation of the capital requirement for interest rate risk is given by ${ }^{5}$

$$
C R_{R}=-\left(1-\phi^{R}-\phi^{B}\right) D_{V} d r^{-} .
$$

To keep the capital requirement for interest rate risk in (9) positive, we assume that pension funds never over-hedge their interest rate risk exposure, so that $\phi^{R}+\phi^{B} \leq 1{ }^{6}$

\subsubsection{Capital requirement for foreign exchange rate risk}

Pension funds hedge foreign exchange rate risk typically with currency forwards. Exchange rate risk occurs when the liabilities are dominated in one currency and the investments in another currency. The capital requirement depends on the part of the exchange rate risk that is not hedged with forwards. We consider a decrease in the foreign exchange rate $d F X^{-}$because this lowers the value of the assets in the local currency. The capital requirement for exchange rate risk equals

$$
C R_{F X}=-w^{F X}\left(1-\phi^{F X}\right) d F X^{-} .
$$

Adding (9) and (10) together gives us the total capital requirement $C R$, again relative to $V$, as

$$
C R=-\left(1-\phi^{R}-\phi^{B}\right) D_{V} d r^{-}-w^{F X}\left(1-\phi^{F X}\right) d F X^{-} .
$$

\subsection{Overall liquidity and capital requirements}

We will combine the liquidity and capital requirements to derive the overall impact on investment policy. In order to do that we make the following three assumptions. First, we assume that capital and margin requirements are interchangeable. If a pension fund hedges risks with derivatives it will

\footnotetext{
${ }^{5}$ We again exclude the convexity effect here as it only has a small second-order effect on the quantitative results.

${ }^{6}$ This assumption is realistic as the value-weighted average interest rate risk hedging across Dutch pension funds equals $40 \%$, meaning that $\phi^{R}+\phi^{B}=0.40$.
} 
have a lower capital requirement but it will be more exposed to margin calls. Second, we assume that positive and negative shocks in a risk factor are equally likely and that the changes are identical in absolute value. The latter means for interest rate risk is $d r^{+}=-d r^{-}=d r$ and for exchange rate risk is $d F X^{+}=-d F X^{-}=d F X$. This is reasonable as a pension fund cannot ex ante know whether an increase or decrease in the underlying risk factor occurs. Third, we assume that the capital requirements and the margin calls are calibrated with the same probability on the same horizon. We believe this to be reasonable because from a risk management perspective it is logical to measure risk independent of how to manage the risk (via capital or via derivatives).

Under these assumptions, we can combine (8) and (11) to obtain the following total requirement

$$
T R=\frac{1}{D_{V}}+\left(1-\phi^{B}\right) D_{V} d r+w^{F X} d F X
$$

Equation (12) shows that the total requirement is a non-linear function of the liability duration and a linear function of the foreign exchange risk exposure. The reader may notice that Equation (12) does not depend on the swap hedge ratio $\phi^{R}$. The intuition behind this is that in our model a margin call on the swap cancels against the capital requirement. The more a pension fund hedges its interest rate risk with swaps, the higher the liquidity requirement and equally lower the capital requirement. ${ }^{7}$ For the same reason, $\phi^{F X}$ also does not appear in the total requirement (12).

Based on the analysis above we can derive for which pension funds the total requirement $T R$ is least constraining to invest in illiquid assets. For that, we examine how the liability duration of a pension fund impacts the total requirement. We equate the first-order derivative of $T R$ with respect to the liability duration $D_{V}$ to zero, to get

$$
\frac{\mathrm{d} T R}{\mathrm{~d} D_{V}}=-\frac{1}{D_{V}^{2}}+\left(1-\phi^{B}\right) d r=0 .
$$

If we solve this, we find the liability duration for which the total requirement $T R$ is least constraining to be

$$
D_{V}^{*}=\frac{1}{\sqrt{\left(1-\phi^{B}\right) d r}}
$$

Based on this we expect pension funds with a liability duration of around $D_{V}^{*}$ to have the highest exposure to illiquid assets. Pension funds with a higher or a lower liability duration are more constrained by capital and liquidity requirements to invest in illiquid assets.

We illustrate how liability duration impacts the total requirement $T R$ in a stylized, but representative, example. We take the following shocks to calculate the liquidity and capital requirement to be equal to $d r=0.5 \%$ and $d F X=25 \%$. These values are comparable to the ones in Dutch pension funds' regulations and to the calibration in Solvency II regulation. Next, we take a continuum of pension funds that are equal except for their liability duration. We use the following parameter values that match with the average Dutch pension fund: $\phi^{R}=20 \%, \phi^{B}=20 \%, \phi^{F X}=25 \%$, and $w^{F X}=50 \%$. Figure 1 shows how, all else equal, the liquidity, capital, and total requirement depend on the liability duration. From this figure, it follows that the liquidity requirement is a convex decreasing function of $D_{V}$, whereas the capital requirement is a linearly increasing function of $D_{V}$. The total requirement $T R$ is therefore first increasing and then decreasing depending on a pension fund's liability duration. A low total requirement implies that a pension fund has more opportunities to invest in illiquid assets. Thus, our model predicts that the impact of $D_{V}$ on the illiquid assets allocation follows the inverse

\footnotetext{
${ }^{7}$ This is not exactly true in practice, because the total capital requirement takes into account a diversification effect between interest rate risk and other risk factors. This diversification effect however only has a marginal second-order effect on the numerical solution of the model.
} 


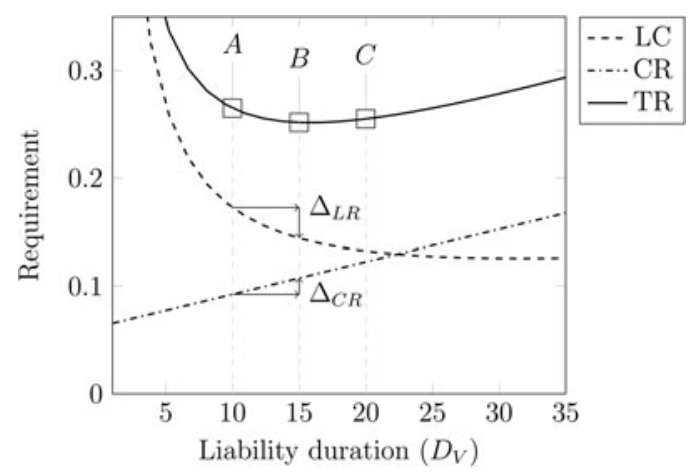

Figure 1. Liquidity requirement, capital requirement, and total requirement as a function of liability duration We use the following parameter values $d r=0.5 \%, \phi^{R}=20 \%, \phi^{B}=20 \%, d F X=$ $25 \%, \phi^{F X}=50 \%$ and $w^{F X}=50 \%$.

shape of the total requirement in Figure 1. In other words, $D_{V}$ creates a hump-shaped effect on the illiquid assets allocation. We will see in Section 4 that our empirical analysis confirms this.

The economic interpretation of Figure 1 is as follows. If we compare pension fund A with a liability duration of 10 years, with pension fund $B$ with a liability duration of 15 years, we see that pension fund $\mathrm{B}$ has a lower total requirement. The lower liquidity requirement of pension fund $\mathrm{B}\left(\Delta_{L R}\right)$ is not fully compensated by a higher capital requirement $\left(\Delta_{C R}\right)$ compared to A. The higher liability duration of B thus creates more opportunities to invest in illiquid assets compared to pension fund $\mathrm{A}$. If we compare pension fund $\mathrm{C}$ with a liability duration of 20 years, with pension fund $\mathrm{B}$, we see the reverse effect. The total requirement of pension fund $\mathrm{C}$ is higher in comparison to pension fund $\mathrm{B}$. Although pension fund $\mathrm{C}$ has a lower liquidity requirement, this is more than fully compensated by a higher capital requirement relative to pension fund $\mathrm{B}$. In Figure 1 the reflection point is at $D_{V}=15.8$. This reflection point will be different for other parameter configurations.

\subsection{Summary of the hypotheses}

In this section, we summarize the hypotheses that follow from our theoretical framework. We expect a hump-shaped impact of liability duration on the illiquid assets allocation and we assess this by adding the square of the liability duration to the regression model. Based on the total requirement in (12) we expect that the swap hedge ratio and the foreign exchange hedge ratio have no effect on the fraction of risky assets invested in illiquid assets. Both the swap and foreign exchange hedge ratios do not appear in the total requirement because the liquidity and capital requirement cancel out against each other. Following (12) we do however expect that the bond hedge ratio will positively impact the illiquid assets allocation. If a pension fund hedges more interest rate risk with bonds it will unlock some of its capital. This can be used to invest a larger fraction of risky assets in illiquid assets. Further, we expect that pension funds that invest more in non-euro dominated assets will allocate less to illiquid assets. A higher exposure to currency risk will seize a larger part of the capital that therefore is less available to invest in illiquid assets.

In the empirical section we will focus on three regression specifications. The main regression uses the fraction of risky assets invested in illiquid assets as the dependent variable. We explain in detail why we use the fraction of risky assets allocated to illiquid assets as dependent variable in Section 4 . In addition to that, we will also assess the impact of liability duration and hedging on the allocation to illiquid assets and on the allocation to risky assets.

\section{Data}

We use quarterly data on $N=219$ Dutch pension funds including their asset allocations, interest rate derivatives, currency derivatives, and other characteristics such as size and pension fund type. The data are free from reporting biases because pension funds report mandatory, following strict reporting 
requirements, to De Nederlandsche Bank the prudential supervisor in the Netherlands. The sample runs from the beginning of 2012 to the end of 2017, or 24 quarters. Following a change in the reporting requirements in 2015, we carefully merge the data before and after 2015 to ensure consistency. ${ }^{8}$ We only consider defined benefit pension funds because those are subject to capital requirements. Because Dutch pension funds cannot go bankrupt, there is no survivorship bias. ${ }^{9}$ We do however exclude pension funds that are 'liquidated' during the sample period. Liquidation means that the pension fund will gradually transfer assets and liabilities to either another pension funds or to an insurance company for cost-efficiency reasons. Because such a gradual transfer of assets may result in non-representative asset allocations we exclude these pension funds. Table 1 shows that in terms of total AUM we only exclude a minor fraction of pension funds this way, about $2 \%$.

\subsection{Assets}

Our data distinguishes between the following 12 assets classes: government bonds, stocks in mature markets, credits, stocks in emerging markets, inflation index-linked bonds, cash and short-term receivables, listed indirect real estate, commodities, non-listed real estate, mortgages, private equity, and hedge funds. ${ }^{10}$ One minus the allocation to government bonds, inflation-index bonds, cash and shortterm receivables is defined as the allocation to risky assets $\left(w^{R I S K Y}\right) .^{11}$

To distinguish between illiquid and liquid asset classes we need to define the concept of liquidity. An asset is considered less liquid if the investor cannot quickly sell a significant quantity of the asset at a price near its fundamental value. Asset classes such as private equity require buyers to have significant capital and particular knowledge about the asset class, which are both often limited in supply. Therefore, the transactions costs of illiquid assets can become substantial. For some illiquid assets, legal impediments make it impossible to trade for a particular time period at all, such as lock-up periods that some hedge funds and private equity funds impose. Certainly, each asset or asset class has some time-varying degree of liquidity. Trading volume in a corporate bond may, e.g., drop to nil if the company runs into a bankruptcy. During the Great Financial Crisis trading in mortgage-backed securities came to a stop. As a result, no clear distinction can be made between liquid and illiquid assets. However, some asset classes are substantially more illiquid than others in terms of the three dimensions (time, quantity, and price) mentioned above. As pension funds are long-term investors, we use immediacy as the key criterion to distinguish between liquid and illiquid asset classes. We classify the sum of non-listed real estate, private equity, mortgages, and hedge funds allocations as the total allocation to illiquid assets $\left(w^{I L L I Q}\right)$. Private equity includes both listed and non-listed private equity, infrastructure investments and micro finance investments. The allocation to private equity contains only the commitments already made, so future commitments are not included. Mortgages contain mortgage-backed securities and direct mortgage lending.

The sum of allocations to stocks in mature markets, credits, stocks in emerging markets, listed indirect real estate and commodities is defined as total allocation to liquid risky assets $\left(w^{L I Q}\right)$. We define the allocation to risky assets equal to the sum of the allocation to risky illiquid assets and the allocation to risky liquid assets

$$
w^{R I S K Y}=w^{I L L I Q}+w^{L I Q} .
$$

Pension funds report both strategic and actual asset allocations. We focus on the strategic asset allocations because those reflect better the decisions made by pension funds. The actual

\footnotetext{
${ }^{8}$ From 2015 onwards the reporting requirements are more granular in order to improve the knowledge on pension fund investment behavior.

${ }^{9}$ As a measure of last resort to prevent bankruptcy pension funds in the Netherlands can reduce accrued pension benefits.

${ }^{10}$ Credits contain all credit related products, e.g., corporate bonds, bank loans, and syndicated loans.

${ }^{11}$ Privately issued inflation-index bonds constitute only a small portion of the market. As a result, we assume that all inflation-index bonds are issued by governments.
} 
Table 1. Total assets under management

\begin{tabular}{lcc}
\hline Year & AUM all pension funds & AUM selected pension funds \\
\hline 2012 & 904.15 & 894.33 \\
2013 & 945.98 & 936.50 \\
2014 & $1,131.74$ & $1,124.42$ \\
2015 & $1,146.66$ & $1,118.72$ \\
2016 & $1,262.54$ & $1,233.41$ \\
2017 & $1,326.07$ & $1,297.67$ \\
$\mathrm{~N}$ & 330 & 219 \\
\hline
\end{tabular}

This table shows the total assets under management in billions of all pension funds (left column) and of the pension funds selected for the analysis (right column) at the end of each year. The total number of pension funds is denoted by $N$. In the analysis, we leave out pension funds that are liquidated during the sample period.

asset allocation, by contrast, is less useful for our research question because it is influenced by market fluctuations and imperfect portfolio rebalancing (Bikker et al., 2010).

Table 2 presents the summary statistics. Panel A highlights the strategic asset allocations. The averages are equally weighted over pension funds and time. Government bonds, stocks mature markets, and credits are the most important asset classes, with average allocations of 33\%, 29\% and $18 \%$, respectively. Concerning the illiquid asset classes, non-listed real estate is the largest asset class with an average allocation of $4 \%$. The 90 th percentile shows that $10 \%$ of the pension funds invest more than $12 \%$ in this asset class. Pension funds on average invest $2 \%$ in mortgages. The other two illiquid asset classes have a strategic allocation of around $1 \%$ on average. Panel A also shows the mean and standard deviation of the actual asset allocations between brackets. The differences between the strategic and actual asset allocations are small suggesting that pension funds on average rebalance their portfolios accurately.

Turning to Panel B, we see that the average allocation to the illiquid assets equals $8 \%$. Approximately one-third of Dutch pension funds do not invest in illiquid assets at all. The 90th percentile however shows that $10 \%$ of the pension funds allocate over $20 \%$ of their total AUM to illiquid assets.

Table 3 shows that the strategic illiquid assets allocation is not fixed and varies over the sample period. This holds for both the aggregate illiquid assets allocation and the illiquid asset classes separately. Pension funds generally review their strategic asset allocation every 3 years. This implies that pension funds on average reviewed there illiquid assets allocation twice during the sample period.

\subsection{Liability duration}

Pension funds report the modified duration of their liabilities $\left(D_{V}\right)$. The liability duration is summarized in Panel B of Table 2. The average liability duration equals 18.9 years. However, $10 \%$ of the pension funds have a liability duration below 14.6 years and $10 \%$ have a liability duration in excess of 23.9 years. This shows there is quite some variation in the average investment horizon of pension funds.

\subsection{Collateral requirements}

Unfortunately, pension funds do not report on their swap hedge ratio or their foreign exchange hedge ratio. However, the data do allow us to calculate the collateral requirements in case of an adverse event in the underlying risk factor, which we argue are good proxies for the swap hedge ratio and the foreign exchange hedge ratio. ${ }^{12}$ We will, therefore, explain in detail how we measure the collateral requirements.

\footnotetext{
${ }^{12}$ As of 2015 , pension funds do report the swap hedge ratio. The correlation between the reported swap hedge ratio and our computation of the collateral requirement on interest rate derivatives equals 0.75 . This shows that our approximation of the swap hedge ratio is not far off.
} 
Table 2. Descriptive statistics

\begin{tabular}{|c|c|c|c|c|c|c|}
\hline & Mean & std. dev. & $\mathrm{p} 10$ & p50 & p90 & obs. \\
\hline \multicolumn{7}{|l|}{ Panel A: asset allocations } \\
\hline \multicolumn{7}{|l|}{ Liquid assets } \\
\hline Government bonds & $0.33(0.31)$ & $0.20(0.21)$ & 0.05 & 0.33 & 0.60 & 4,956 \\
\hline Stocks mature markets & $0.29(0.30)$ & $0.13(0.13)$ & 0.16 & 0.27 & 0.43 & 4,956 \\
\hline Credits & $0.18(0.19)$ & $0.12(0.11)$ & 0.00 & 0.17 & 0.34 & 4,956 \\
\hline Stocks emerging markets & $0.05(0.05)$ & $0.04(0.04)$ & 0.00 & 0.05 & 0.10 & 4,956 \\
\hline Inflation index-linked bonds & $0.02(0.02)$ & $0.05(0.05)$ & 0.00 & 0.00 & 0.08 & 4,956 \\
\hline Listed real estate & $0.02(0.03)$ & $0.03(0.04)$ & 0.00 & 0.00 & 0.05 & 4,956 \\
\hline Commodities & $0.01(0.01)$ & $0.02(0.02)$ & 0.00 & 0.00 & 0.05 & 4,956 \\
\hline Cash and short-term receivables & $0.01(0.03)$ & $0.07(0.08)$ & 0.00 & 0.00 & 0.03 & 4,956 \\
\hline \multicolumn{7}{|l|}{ Illiquid assets } \\
\hline Non-listed real estate & $0.04(0.04)$ & $0.05(0.05)$ & 0.00 & 0.03 & 0.12 & 4,956 \\
\hline Mortgages & $0.02(0.02)$ & $0.04(0.04)$ & 0.00 & 0.00 & 0.07 & 4,956 \\
\hline Private equity & $0.01(0.01)$ & $0.02(0.02)$ & 0.00 & 0.00 & 0.05 & 4,956 \\
\hline Hedge funds & $0.01(0.01)$ & $0.02(0.02)$ & 0.00 & 0.00 & 0.04 & 4,956 \\
\hline \multicolumn{7}{|l|}{ Panel B: variables } \\
\hline Allocation to illiquid assets & 0.08 & 0.08 & 0.00 & 0.06 & 0.20 & 4,956 \\
\hline Allocation to risky assets & 0.64 & 0.18 & 0.40 & 0.65 & 0.90 & 4,956 \\
\hline Fraction illiquid in risky assets & 0.13 & 0.12 & 0.00 & 0.11 & 0.30 & 4,904 \\
\hline Liability duration & 18.90 & 3.98 & 14.60 & 18.60 & 23.90 & 4,978 \\
\hline CR on interest rate derivatives & 0.05 & 0.04 & 0.00 & 0.04 & 0.10 & 4,973 \\
\hline CR on currency derivatives & 0.05 & 0.04 & 0.00 & 0.05 & 0.10 & 4,991 \\
\hline Bond hedge ratio & 0.25 & 0.14 & 0.09 & 0.22 & 0.45 & 4,940 \\
\hline Foreign investments & 0.22 & 0.22 & 0.00 & 0.20 & 0.51 & 3,682 \\
\hline Log of total AUM & 5.84 & 0.81 & 5.00 & 5.79 & 6.86 & 4,997 \\
\hline Required funding ratio & 1.16 & 0.07 & 1.10 & 1.16 & 1.23 & 4,992 \\
\hline Funding ratio $(t-1)$ & 1.09 & 0.13 & 0.96 & 1.07 & 1.22 & 4,992 \\
\hline
\end{tabular}

Panel A provides summary statistics of pension funds' strategic asset allocation. The means and standard deviations of the actual asset allocation are shown between brackets. Panel B provides the summary statistics of the variables specified in Section 3: allocation to

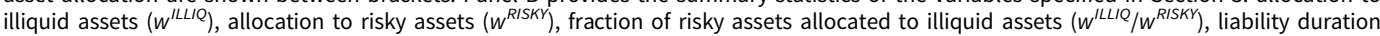
$\left(D_{V}\right)$, collateral requirements on interest rate derivatives $(C R r)$, collateral requirements on currency derivatives $(C R f x)$, bond hedge ratio $\left(\phi^{B}\right)$, fraction of investments outside euro area $\left(w^{F X}\right), \log$ of total AUM (Size), required funding ratio $(R f r)$, and one period lag of the actual funding ratio (Fr). The summary statistics are computed as the equally weighted average over all pension funds and all quarters in the 2012-2017 period.

Pension funds report the market value of the total interest rate derivatives and currency derivatives that they have entered into. In addition, they also report the expected values of these positions after some predefined shocks in the underlying risk factors. For interest-rate risk these shocks are an increase (decrease) in the term structure of market interest rates of 1 percentage points and for foreign exchange risk an appreciation (depreciation) of foreign currencies with respect to the euro of $25 \%$.

The collateral requirement on interest rate derivatives $(C R r)$ is the absolute difference between the market value of the portfolio of derivatives after a predetermined shock, $M V r_{s}$, minus its current market value, $M V r_{c}$. We divide the absolute value of this difference by the total AUM

$$
C R r=\frac{\left|M V r_{s}-M V r_{c}\right|}{A U M}
$$

We define the collateral requirements on currency derivatives (CRfx) as the absolute difference between the market value of the portfolio of derivatives after a predetermined shock, $M V f x_{s}$, minus its current market value, $M V f x_{c}$. We express the absolute value of the change relative to the total AUM

$$
C R f x=\frac{\left|M V f x_{s}-M V f x_{c}\right|}{A U M} .
$$

We determine the collateral requirements by using an increase in the interest rate of 1 percentage points and an increase of the foreign currency relative to the euro of $25 \%$. The collateral requirements 
Table 3. Time variation in the strategic illiquid assets allocation

\begin{tabular}{lc}
\hline Illiquid asset class & Average time variation \\
\hline Total illiquid assets & 0.0251 \\
Non-listed real estate & 0.0146 \\
Mortgages & 0.0153 \\
Private equity & 0.0040 \\
Hedge funds & 0.0048 \\
\hline
\end{tabular}

This table shows the cross-sectional average time variation of pension fund's illiquid assets allocation over the period 2012-2017. The average time variation is computed as the cross-sectional average of the standard deviation of pension funds' strategic illiquid assets allocations over time.

on interest rate derivatives and on currency derivatives are summarized in Panel B of Table 2. The averages of both are of the same order of magnitude and equal 5\% of AUM. The 10th percentiles are in both cases equal to zero, revealing that some pension funds do not hedge these risks with derivatives at all.

\subsection{Bond hedge ratio and foreign investments}

Our theoretical model in (12) shows that the bond hedge ratio $\left(\phi^{B}\right)$ and the fraction invested outside the euro area $\left(w^{F X}\right)$ affect the illiquid assets allocation. Table 2 shows that pension fund on average hedge $25 \%$ of their liability interest rate risk with bonds. About $10 \%$ of the pension funds in the sample have a bond hedge ratio in excess of $45 \%$. The fraction investments outside the euro area equals $22 \%$ on average and $51 \%$ in the 90 th percentile. In our theoretical model, we express all results relative to the liabilities. Here we take both the bond hedge ratio and the foreign investments as a fraction of total AUM to make the quantities easier to interpret. Expressing the quantities in either AUM or liabilities does however not materially affect our empirical analysis.

\subsection{Control variables}

As control variables, we include the log of total AUM (Size), pension fund type (Type), the required funding ratio $(R f r)$, and the actual funding ratio at the end of the previous period $(F r)$. We distinguish between three types of pension funds. There are 55 industry-wide pension funds, 10 professional group pension funds and 154 corporate pension funds in the sample. Industry-wide pension funds are generally mandatory pension funds and organize pensions for a specific industry or sector, e.g., civil servants or hospital staff. Professional group pension funds provide pensions for a single profession such as hairdressers or pharmacists. Corporate pension funds arrange pensions for a particular company.

The level of the required funding ratio to comply with regulations depends on the specific risk profile of a pension fund. ${ }^{13}$ Including the required funding ratio in the regression model, therefore, controls for differences in risk appetite. For instance, a 'young' pension fund (with a high liability duration) could substantially differ in its risk appetite compared to an 'old' pension fund (with a low liability duration), potentially driving the impact of liability duration on the illiquid assets allocation. Furthermore, pension funds that hedge only a small part of their interest rate risk or currency risk could be the ones that take more risk in general, potentially driving the effect of hedging on the illiquid assets allocation.

The actual, previous period, funding ratio is also included in the analysis. From the literature on risktaking behavior of pension funds, the actual funding ratio could either have a positive or a negative effect on the illiquid assets allocation. Basak and Shapiro (2001) show that, compared to normal circumstances, investors take more risk in worst-case scenarios when they are subjected to a VaR requirement. On the other hand, Rauh (2009), using US corporate defined benefit pension funds data, finds that poorly funded pension plans allocate a larger share of their assets to government bonds.

\footnotetext{
${ }^{13}$ The risk profile is measured by the 'mismatch' between assets and liabilities.
} 
Size, required funding ratio and actual funding ratio are summarized in Panel B, Table 2. The 10th and 90th percentile of the log of total AUM reveal that the size distribution is right-skewed: the largest pension funds in our sample are considerably larger compared to the mean pension fund. The average required funding ratio equals $116 \%$ and varies from $110 \%$ to $123 \%$. The actual funding ratio equals $109 \%$ on average, which is substantially below the required funding ratio of pension funds.

Table 4 splits the sample in pension funds that invest and that do not invest in illiquid assets. The latter group takes less risk in general, having on average a 10 percentage points lower risky assets allocation. The table also reveals that the average size of pension funds that do not invest in illiquid assets is considerably smaller. On other dimensions however, the subsamples are comparable.

\section{Allocation to illiquid assets: empirical results}

To measure the impact of liquidity and capital requirements on the illiquid assets allocation, we estimate a static random effects Tobit model. ${ }^{14}$ The Tobit model controls for left-censoring of the allocation to illiquid assets at zero. This is necessary as a substantial number of pension funds does not invest in illiquid assets. Asset allocation decisions are typically first made to very broad asset classes such as safe assets (bonds) and risky assets (stocks). In a second step, asset allocations are determined within each broad asset class (Binsbergen et al., 2008). Following this top-down decisionmaking process, we first analyze the aggregate illiquid assets allocation. Because illiquid asset classes differ in their degree of immediacy, we look at individual illiquid asset classes separately in the next section.

We will however not assess the illiquid assets allocation directly. Instead, we will take the fraction of risky assets invested in illiquid assets as our key dependent variable. The main reason to take this fraction is to circumvent mechanical effects. The following two examples show these mechanical effects. First, suppose that a pension fund decides to invest more in bonds, this mechanically results in a lower allocation to risky assets and therefore, potentially, also a lower allocation to illiquid assets. Second, Dutch pension funds invest the majority of their bond portfolio in the euro area, whereas the risky assets are generally invested more globally. Currency hedging is therefore directly related to the risky assets allocation. A positive effect of currency hedging on the illiquid assets allocation could, therefore, be mechanical.

In alternative model specifications we nonetheless also use the allocation to illiquid assets $\left(w^{I L L I Q}\right)$ and to risky assets $\left(w^{R I S K Y}\right)$ as dependent variables. In the latter case, we estimate a standard random effects model as there is no censoring around zero.

The general model specification is

$$
\begin{aligned}
\frac{w_{i t}^{I L L I Q}}{w_{i t}^{R I S K Y}}=\beta_{0} & +\beta_{1} D_{V, i t}+\beta_{2} D_{V, i t}^{2}+\beta_{3} C R r_{i t}+\beta_{4} C R f x_{i t}+\beta_{5} \phi_{i t}^{B}+\beta_{6} w_{i t}^{F X} \\
& +\beta_{7} \text { Size }_{i t}+\beta_{8} \text { Type }_{i}+\beta_{9} R f r_{i t}+\beta_{10} F r_{i t-1}+\lambda_{t}+\epsilon_{i t}
\end{aligned}
$$

where $w_{i, t}$ indicates the allocation of pension fund $i=1, \ldots, N$ at the end of the quarter $t=2012 Q 1, \ldots$, 2017Q4. The main explanatory variables are the liability duration $\left(D_{V}\right)$, the square of the liability duration $\left(D_{V}^{2}\right)$, the collateral requirements on interest rate derivatives $(C R r)$, the collateral requirements on currency derivatives $(C R f x)$, the bond hedge ratio $\phi^{B}$, and the fraction of total foreign investments $w^{F X}$. To link the main regression specification directly to our theoretical framework, we recall from the previous section that $C R r$ proxies for the swap hedge ratio $\phi^{R}$ and $C R f x$ proxies for the foreign exchange hedge ratio $\phi^{F X}$. The control variables are the log of total AUM (Size), the pension fund type (Type), the required funding ratio $(R f r)$ and the lag of the actual funding ratio $(F r)$. We include dummies for

\footnotetext{
${ }^{14} \mathrm{~A}$ random effects structure corrects for time-invariant pension funds' characteristics that we do not observe but potentially play a role in investment decisions.
} 
Table 4. Descriptive statistics - subsamples

\begin{tabular}{|c|c|c|c|c|c|}
\hline & Mean & std. dev. & $\mathrm{p} 10$ & p50 & p90 \\
\hline \multicolumn{6}{|c|}{ Panel A: pension funds that invest in illiquid assets } \\
\hline Allocation to illiquid assets & 0.12 & 0.08 & 0.03 & 0.11 & 0.22 \\
\hline Allocation to risky assets & 0.67 & 0.16 & 0.47 & 0.67 & 0.90 \\
\hline Fraction illiquid in risky assets & 0.18 & 0.10 & 0.05 & 0.16 & 0.32 \\
\hline Liability duration & 18.61 & 3.50 & 15.00 & 18.00 & 23.00 \\
\hline $\mathrm{CR}$ on interest rate derivatives & 0.05 & 0.04 & 0.00 & 0.04 & 0.09 \\
\hline CR on currency derivatives & 0.06 & 0.04 & 0.00 & 0.05 & 0.10 \\
\hline Bond hedge ratio & 0.24 & 0.12 & 0.10 & 0.22 & 0.40 \\
\hline Foreign investments & 0.23 & 0.22 & 0.00 & 0.23 & 0.53 \\
\hline Log of total AUM & 6.05 & 0.77 & 5.19 & 5.98 & 7.00 \\
\hline Required funding ratio & 1.17 & 0.07 & 1.11 & 1.17 & 1.24 \\
\hline Funding ratio $(t-1)$ & 1.09 & 0.12 & 0.96 & 1.08 & 1.22 \\
\hline \multicolumn{6}{|c|}{ Panel B: pension funds that do not invest in illiquid assets } \\
\hline Allocation to illiquid assets & 0.00 & 0.00 & 0.00 & 0.00 & 0.00 \\
\hline Allocation to risky assets & 0.57 & 0.22 & 0.30 & 0.56 & 0.91 \\
\hline Fraction illiquid in risky assets & 0.00 & 0.00 & 0.00 & 0.00 & 0.00 \\
\hline Liability duration & 20.00 & 4.88 & 14.00 & 20.00 & 26.00 \\
\hline $\mathrm{CR}$ on interest rate derivatives & 0.05 & 0.05 & 0.00 & 0.05 & 0.12 \\
\hline CR on currency derivatives & 0.04 & 0.04 & 0.00 & 0.03 & 0.09 \\
\hline Bond hedge ratio & 0.28 & 0.18 & 0.08 & 0.23 & 0.58 \\
\hline Foreign investments & 0.18 & 0.19 & 0.00 & 0.12 & 0.44 \\
\hline Log of total AUM & 5.28 & 0.62 & 4.65 & 5.30 & 6.03 \\
\hline Required funding ratio & 1.15 & 0.06 & 1.08 & 1.14 & 1.22 \\
\hline Funding ratio $(t-1)$ & 1.10 & 0.16 & 0.95 & 1.07 & 1.24 \\
\hline
\end{tabular}

This table specifies the summary statistics of the variables specified in Section 3 for pension funds that do invest in illiquid assets (Panel A) and pension funds that do not invest in illiquid assets (Panel B): allocation to illiquid assets ( $w^{\text {ILLIO }}$ ), allocation to risky assets ( $w^{\text {RISKY }}$ ), fraction of risky assets allocated to illiquid assets $\left(w^{I L L I Q} / w^{R I S K Y}\right)$, liability duration $\left(D_{V}\right)$, collateral requirements on interest rate derivatives (CRr), collateral requirements on currency derivatives $(C R f x)$, bond hedge ratio $\left(\phi^{B}\right)$, fraction of investments outside euro area $\left(w^{F X}\right)$, log of total AUM (Size), required funding ratio (Rfr), and the one-period lag of the actual funding ratio ( $F r)$. The summary statistics are computed as the equally weighted average over all pension funds and all quarters in the 2012-2017 period.

the pension fund type, where the reference group consists of industry-wide pension funds. A professional group pension fund is denoted by dummy Prof and a corporate pension fund by dummy Corp. The fall in market interest rates over our sample period may have caused pension funds to increase their allocation towards illiquid assets in a search for yield (Boubaker et al., 2017). Therefore, we control for time-fixed effects $(\lambda)$ in all our model specifications.

Another potential concern is that pension funds with a high liability duration are more likely to hedge interest rate risk using swaps. The reason for this is that there are not sufficient long-term government bonds available to match with the duration of long-term pension liabilities. This issue is more severe for pension funds with a high liability duration. Therefore liability duration $D_{V}$ and collateral requirement for interest rate risk $C R r$ may be correlated. Table 5 shows that there is indeed a positive correlation between $D_{V}$ and $C R r$, however, given a value of 0.40 collinearity should not be an issue. This implies that the results for $D_{V}$ and $C R r$ can be interpreted separately. ${ }^{15}$

\subsection{Liability duration}

Table 6 shows the results for the main model specification in (15). The first column shows that liability duration has a positive effect on the fraction of risky assets allocated to illiquid assets, whereas the square of the liability duration has a negative impact. Both coefficients are statistically significant at

\footnotetext{
${ }^{15}$ We also run our models to test for a possible interaction between liability duration and collateral requirements. The interaction term between both variables however is statistical not different from zero in all of the model specifications. These results are available upon request. Further, the liability duration $\left(D_{v}\right)$ is negatively correlated with bond hedge ratio $\left(\phi^{B}\right)$ as well as the lagged funding ratio $(F r)$. The variance inflation factor for liability duration equals $1 / 1-R^{2}=1.15$, which is far below the threshold for multicollinearity issues (10), and hence multicollinearity is not an issue here.
} 
the $1 \%$ significance level. This means that there is indeed a hump-shaped relationship. Up to a liability duration of 18 years $\left(\left(\left(\partial w^{I L L I Q} / w^{R I S K Y}\right) / \partial D_{V}\right)=\beta_{1}+2 \beta_{2} D_{V}=0 \rightarrow D_{V}=-\left(\beta_{1} / 2 \beta_{2}\right)\right)$, the effect of liability duration is positive. After this point, however, the effect reverses. The fraction of illiquid assets for a pension fund with a liability duration of 11 years is 1.07 percentage points higher compared to a pension fund with a liability duration of 10 years. A pension fund with a liability duration of 26 years allocates 1.02 percentage points less to illiquid assets compared to pension funds with a 25 -year duration. ${ }^{16}$ Figure 2 shows the estimated hump-shaped impact of liability duration on the fraction of the risky assets allocated to illiquid assets.

The results are in line with our theoretical predictions. Up to a liability duration of 18 years, the liquidity requirement decreases faster than the capital requirement increases. A pension fund with a high liability duration has less short-term liabilities relative to a pension fund with a low liability duration. A high liability duration implies that it is less of a constraint for a pension fund not being able to trade frequently in illiquid assets. Beyond a liability duration of 18 years however, the capital requirement increases faster than the liquidity requirement decreases. This lowers the opportunity to invest in illiquid assets.

As an alternative specification, we use the allocation to illiquid risky assets $w^{I L L I Q}$ (Table 6, Column (2)). Again, a hump-shaped impact of liability duration on the illiquid assets allocation appears. We also assess the allocation to risky assets $w^{R I S K Y}$. Table 6, Column (3) shows a negative impact of liability duration on the risky assets allocation, while the duration squared is positive. Figure 3 plots the combined impact on the allocation to risky assets. The increase in the risky asset allocation on the right-hand side of this figure coincides with the findings in Andonov et al. (2017), who find that the investment policy of public and private European and Canadian pension funds and private US pension funds is more aggressive for less mature pension funds. A study by Alestalo and Puttonen (2006) reports similar findings for Finnish pension funds. However, Figure 3 also highlights on the left-hand side that mature pension funds invest more in risky assets compared to pension funds with an average liability duration. A possible explanation is that mature pension funds can more easily hedge their liabilities with bonds instead of swaps and can consequently use their capital for risk-taking.

In Column (4) of Table 6, we use actual rather than strategic asset allocations. We observe the following. First, the liability duration has again hump-shaped impact on the fraction of risky assets allocated to illiquid assets. The reflection point is now at a liability duration of 15.0 years. Second, the hedging of interest rate risk and currency risk does not affect the fraction of risky assets allocated to illiquid assets. Third, foreign investments have a significant and positive impact. Although these results seem to better support or theoretical predictions, using actual instead of strategic asset allocations might cause effects that are (partly) driven by the performance of the different asset classes or imperfect rebalancing by pension funds.

\subsection{Collateral requirements}

Table 6 shows that the collateral requirements on interest rate swaps $(C R r)$ do not have an effect on the allocation to illiquid assets. This is in line with the theoretical predictions of our model: the liquidity and capital requirement cancel out against each other. However, we do find a significant and positive impact of collateral requirements on currency forwards. At first glance, this result seems to conflict the predictions of our model. However, in practice collateral requirements for currency forwards are less strict than for interest rate swaps and in some cases even non-existent. In our theoretical framework, this implies that the increase in liquidity requirements for currency risk hedging is smaller than the

\footnotetext{
${ }^{16}$ Notice that the coefficients are estimates based on the uncensored latent variable, not the observed outcome. The coefficients are the right interpretation for all observations on the dependent variable, $w^{I L L I Q} / w^{R I S K Y}$, above zero. In order to get the effect on the actual observed dependent variable, the coefficient estimates have to be multiplied by the probability of the dependent variable being above zero.
} 
Table 5. Correlation table of key variables

\begin{tabular}{|c|c|c|c|c|c|c|c|c|}
\hline \multicolumn{9}{|c|}{ Correlation matrix } \\
\hline & $D_{V}$ & $C R r$ & CRfx & $\phi^{B}$ & $w^{F X}$ & Size & Rfr & $\overline{F r}$ \\
\hline$\overline{D_{V}}$ & 1 & & & & & & & \\
\hline$C R r$ & 0.40 & 1 & & & & & & \\
\hline$C R f x$ & 0.02 & 0.12 & 1 & & & & & \\
\hline$\phi^{B}$ & -0.29 & -0.40 & -0.24 & 1 & & & & \\
\hline$w^{F X}$ & 0.20 & 0.01 & 0.27 & -0.17 & 1 & & & \\
\hline Size & 0.04 & 0.06 & 0.21 & -0.15 & 0.28 & 1 & & \\
\hline Rfr & 0.12 & -0.17 & 0.13 & -0.24 & 0.29 & 0.16 & 1 & \\
\hline$F r$ & -0.33 & -0.19 & -0.08 & 0.06 & -0.07 & -0.15 & -0.02 & 1 \\
\hline
\end{tabular}

This table provides the correlation matrix of the key variables: liability duration $\left(D_{V}\right)$, collateral requirements on interest rate derivatives (CRr), collateral requirements on currency derivatives $(C R f X)$, bond hedge ratio $\left(\phi^{B}\right)$, fraction of investments outside euro area $\left(w^{F X}\right)$, log of total AUM (Size), required funding ratio $(R f r)$, and the one period lag of the actual funding ratio $(F r)$.

decrease in the capital requirement. This creates opportunities to invest in illiquid assets. A one standard deviation increase in the collateral requirements (an increase of 0.04 CRfx) implies an increase in the fraction of risky assets allocated to illiquid assets of approximately 0.71 percentage points. The average fraction of risky assets allocated to illiquid assets of the pension funds that have a positive allocation to illiquid assets equals $18 \%$. This implies a relative increase in the fraction of risky assets allocated to illiquid assets of approximately $4.0 \%$.

The impact of collateral requirements on the allocation to risky assets is also shown in Table 6, Column (3). The findings are comparable to the effects of the fraction of risky assets invested in illiquid assets. Notice that we control for the total fraction invested in foreign currencies such that the results we obtain are not mechanical. A one standard deviation increase in the collateral requirement (an increase of $0.04 C R f x$ ) implies an increase in the risky assets allocation of approximately 1.64 percentage points. This implies a relative increase in the risky asset allocation of $2.6 \%$. Taken together, a larger foreign exchange hedge ratio increases the allocation to risky assets which in turn increases the fraction of risky assets that is allocated to illiquid assets.

\subsection{Bond hedge ratio and foreign investments}

We do not find a statistically significant effect of the bond hedge ratio on the fraction allocated to illiquid assets, although the sign of the coefficient is in line with our theoretical framework. The bond hedge ratio negatively affects the allocation to illiquid assets and to risky assets. The latter, however, is a mechanical effect because hedging interest rate risk with bonds by construction lowers the allocation to risky assets.

We also do not find an effect of foreign investments on the fraction invested in illiquid assets, although the sign of the coefficient is again in line with our model. The same is true for the impact on the illiquid assets allocation. The fraction invested in foreign assets has a significant negative impact on risky assets allocation. Investing more in foreign currencies, while keeping hedging fixed, increases the capital requirement and therefore limits opportunities to invest in risky assets. A 10 percentage points increase in the fraction invested in foreign assets decreases the risky assets allocation with 1.35 percentage points.

\subsection{Control variables}

We now turn to the control variables. Table 6 shows that size has a positive and significant impact on the allocation to illiquid assets. A pension fund that is ten times larger in terms of total AUM allocates a 7.4 percentage points higher fraction of risky assets allocated to illiquid assets. Illiquid assets are generally complex investment products and therefore the pension fund needs to have sufficient knowledge 
Table 6. Main results - Total illiquid assets

\begin{tabular}{|c|c|c|c|c|}
\hline Dependent variable & $\begin{array}{c}(1) \\
w^{I L L I Q} / w^{R I S K Y}\end{array}$ & $\begin{array}{c}(2) \\
w^{I L L I Q}\end{array}$ & $\begin{array}{c}(3) \\
w^{R I S K Y}\end{array}$ & $\begin{array}{c}(4) \\
w^{I L L I Q} / w^{R I S K Y}\end{array}$ \\
\hline$D_{V}$ & $\begin{array}{l}0.0254^{\star * \star} \\
(0,056)\end{array}$ & $\begin{array}{l}0.0126^{\star \star \star} \\
(0.0039)\end{array}$ & $\begin{array}{l}-0,404^{\star \star \star} \\
(0.0062)\end{array}$ & $\begin{array}{l}0.0120^{\star \star} \\
(0.0050)\end{array}$ \\
\hline$D_{V}^{2}$ & $\begin{array}{c}-0.0007^{\star \star \star} \\
(0.0001)\end{array}$ & $\begin{array}{l}-0.0004^{\star \star *} \\
(0.0001)\end{array}$ & $\begin{array}{l}0.0009^{\star \star \star *} \\
(0.0002)\end{array}$ & $\begin{array}{c}-0.0004^{\star * \star} \\
(0.0001)\end{array}$ \\
\hline$C R r$ & $\begin{array}{c}-0.0124 \\
(0.0576)\end{array}$ & $\begin{array}{c}-0.0141 \\
(0.0405)\end{array}$ & $\begin{array}{r}-0.0208 \\
(0.0713)\end{array}$ & $\begin{array}{c}0.0355 \\
(0.0517)\end{array}$ \\
\hline CRfx & $\begin{array}{l}0.1784^{\star \star \star} \\
(0.0363)\end{array}$ & $\begin{array}{l}0.1371^{\star \star *} \\
(0.0255)\end{array}$ & $\begin{array}{l}0.4104^{\star \star \star} \\
(0.0481)\end{array}$ & $\begin{array}{c}0.0151 \\
(0.0325)\end{array}$ \\
\hline$\phi^{B}$ & $\begin{array}{c}0.0204 \\
(0.0181)\end{array}$ & $\begin{array}{l}-0.0761^{\star \star \star} \\
(0.0127)\end{array}$ & $\begin{array}{c}-0.4038^{\star \star \star} \\
(0.0220)\end{array}$ & $\begin{array}{c}0.0127 \\
(0.0162)\end{array}$ \\
\hline$w^{F X}$ & $\begin{array}{c}-0.0125 \\
(0.0125)\end{array}$ & $\begin{array}{c}-0.0013 \\
(0.0088)\end{array}$ & $\begin{array}{c}-0.1342^{\star \star \star} \\
(0.0152)\end{array}$ & $\begin{array}{l}0.0424^{\star \star \star} \\
(0.0108)\end{array}$ \\
\hline Size & $\begin{array}{l}0.0736^{\star \star \star} \\
(0.0102)\end{array}$ & $\begin{array}{l}0.0566^{\star \star \star} \\
(0.0075)\end{array}$ & $\begin{array}{l}0.0604^{\star \star \star} \\
(0.0098)\end{array}$ & $\begin{array}{l}0.0625^{\star \star *} \\
(0.0093)\end{array}$ \\
\hline Corp & $\begin{array}{l}-0.0757^{\star \star \star} \\
(0.0217)\end{array}$ & $\begin{array}{c}-0.0454^{\star \star \star} \\
(0.0143)\end{array}$ & $\begin{array}{c}0.0218 \\
(0.0194)\end{array}$ & $\begin{array}{c}-0.0535^{\star \star \star} \\
(0.0173)\end{array}$ \\
\hline Prof & $\begin{array}{c}0.0184 \\
(0.0438)\end{array}$ & $\begin{array}{c}0.0068 \\
(0.0288)\end{array}$ & $\begin{array}{r}-0.0234 \\
(0.0380)\end{array}$ & $\begin{array}{c}0.0053 \\
(0.0341)\end{array}$ \\
\hline Rfr & $\begin{array}{c}-0.0006 \\
(0.0190)\end{array}$ & $\begin{array}{c}0.0045 \\
(0.0133)\end{array}$ & $\begin{array}{c}0.0192 \\
(0.0277)\end{array}$ & $\begin{array}{l}0.0608^{\star \star \star} \\
(0.0180)\end{array}$ \\
\hline $\mathrm{Fr}$ & $\begin{array}{c}-0.0686^{\star \star} \\
(0.0275)\end{array}$ & $\begin{array}{l}-0.0562^{\star \star \star} \\
(0.0192)\end{array}$ & $\begin{array}{c}-0.0723^{\star \star} \\
(0.0304)\end{array}$ & $\begin{array}{c}-0.1418^{\star \star} \\
(0.0245)\end{array}$ \\
\hline Time FE & Y & Y & Y & Y \\
\hline$N$ & 3,401 & 3,401 & 3,433 & 3,400 \\
\hline Left-censored & 877 & 890 & $\mathrm{n} / \mathrm{a}$ & 606 \\
\hline Uncensored & 2,524 & 2,511 & $\mathrm{n} / \mathrm{a}$ & 2,794 \\
\hline
\end{tabular}

In this table, we show the random effects estimators based on the regression (15). The dependent variable in the first column is the strategic fraction of risky assets allocated to illiquid assets $\left(w^{\prime L L I Q} / w^{R I S K Y}\right)$, the dependent variable in the second column is the strategic allocation to

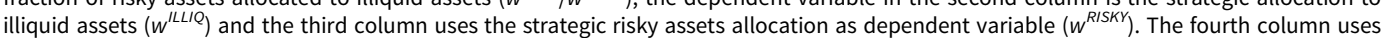
actual rather than strategic allocations. The independent variables include the liability duration $\left(D_{V}\right)$, the liability duration squared $\left(D_{V}^{2}\right)$, the collateral requirements on interest rate derivatives $(C R r)$, the collateral requirements on currency derivatives $(C R f x)$, bond hedge ratio $\left(\phi^{B}\right)$, fraction of foreign investments $\left(w^{F X}\right)$, the log of total AUM (Size), Corp indicates a corporate pension fund, Prof indicates a professional pension fund, $R f r$ is the required funding ratio, and $F r$ the one-period lag of the actual funding ratio. Standard errors are between parentheses; ${ }^{*} p<0.10$; ${ }^{* *} p<0.05 ; p<0.01$.

Figure 2. The effect of the liability duration on the fraction of risky assets allocated to illiquid assets The calculations are based on assuming an industry-wide pension fund that has average foreign exchange risk hedging activities, average size, and average lag funding ratio (other variables are set equal to zero as they are not statistically significant). The dashed line represents the $95 \%$ confidence interval.

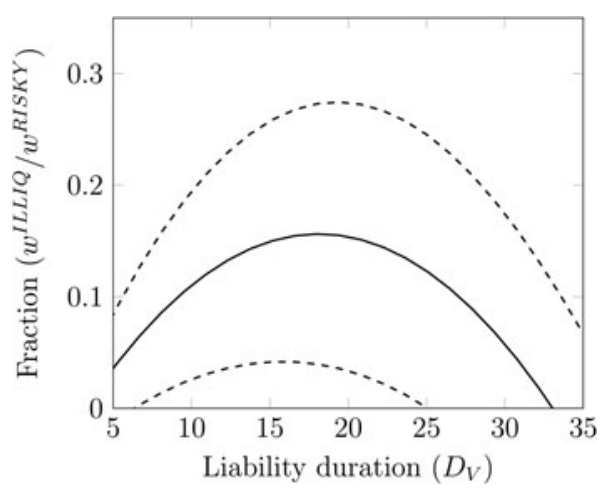

to manage these products. The larger a pension fund, the better it can afford to pay the costs involved in managing complex investment products. Our finding is consistent with Andonov (2014) and Dyck and Pomorski (2016), who show that the increase in the allocation to illiquid assets is more pronounced for large institutional investors. Moreover, Stoughton and Zechner (2011) argue that economies of scale in alternative assets exist because only large investors can afford to pay high fixed search costs to identify profitable projects or select skilled external managers. On top of that, large 


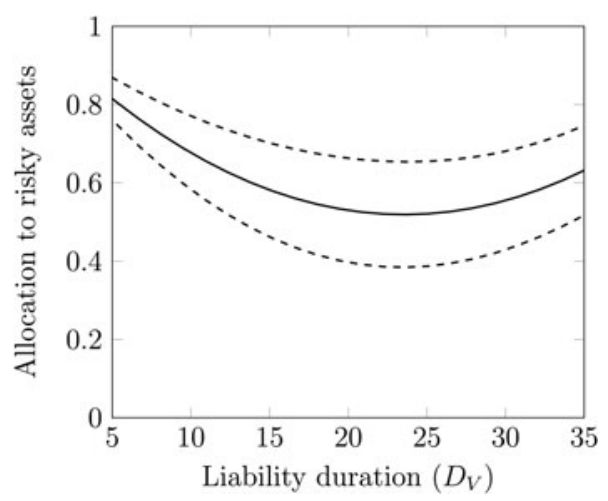

Figure 3. The effect of the liability duration on the risky assets allocation The calculations are based on assuming an industry-wide pension fund that has average foreign exchange risk hedging activities, average bond hedging activities, average foreign investments, average size, and average lag funding ratio (other variables are set equal to zero as they are not statistically significant). The dashed line represents the $95 \%$ confidence interval.

institutional investors have more power to negotiate better fees (Broeders et al., 2016). Table 6 also shows that large pension funds invest more in risky assets in general, although the economic impact is somewhat smaller. A pension fund that is ten times larger invests 6.0 percentage points more in risky assets.

We also find that corporate pension funds allocate significantly less to illiquid assets as a fraction of risky assets compared to industry-wide pension funds. We believe that this difference is due to the fact that a corporation is required to report on its pension fund in the annual accounts and is, therefore, less willing to take risks. Indeed, the riskiness of a corporate pension plan impacts the risk profile of the corporation (Jin et al., 2006). An additional explanation is that corporate pension funds are more exposed to sponsor default risk compared to compulsory and professional group pension funds. Therefore, they are less willing to take risk (Broeders, 2010).

Finally, the required funding ratio does not affect asset allocations, while the lag of the actual funding ratio affects all allocations in Table 6 negatively. This implies that pension funds with a lower last period funding ratio invest a larger fraction of their risky assets in illiquid assets. This result supports the theoretical finding by Basak and Shapiro (2001) that pension funds for which a VaR requirement is binding take additional investment risks. This finding is also consistent with the empirical study of Peng and Wang (2019), who study alternative investments decisions of US public pension plans, and find that pension plans with lower funding ratios allocate more to alternative assets. A one standard deviation decrease in the previous period funding ratio increases the fraction of risky assets allocated to illiquid assets by 0.89 percentage points. Pension funds also increase the total risky assets allocation when the previous period funding ratio decreased. In other words, a lower funding ratio implies a higher total risky assets allocation and a larger fraction of the risky assets allocation is invested in illiquid assets.

\subsection{Empirical results separate illiquid asset classes}

So far, we treated illiquid asset classes as a homogeneous group. However, the degree of immediacy differs across separate illiquid asset classes. For instance, the typical time between transactions for residential housing is 4 and 5 years, although it can vary from months to decades (Hansen, 1998) and (Miller et al., 2011). The average time between transactions is relatively high in case of private equity. Private equity investments generally run for 10 years and trading before a contract expires is unusual (Metrick and Yasuda, 2010).

To reflect these differences in immediacy, Table 7 presents the results for the following illiquid asset classes separately: real estate, mortgages, private equity and hedge funds. The hump-shaped effect of the liability duration on the fraction of risky assets allocated to illiquid assets is present in all four asset classes. The cut-off point where the marginal benefits (lower liquidity requirement) and the marginal costs (higher capital requirement) of a higher liability duration are equal, is close to the aggregate cutoff point of 18 for the overall fraction of risky assets allocated to illiquid assets. 
The results of swap hedge ratios are however mixed across the different asset classes. Consistent with the aggregated results, the swap hedge ratio does not affect the allocation to real estate and mortgages. In the case of private equity, the swap hedge ratio positively affects the real estate allocation. Notice that the economic magnitude is however small. A one standard deviation increase in collateral requirement leads to an increase of the fraction of risky assets allocated to private equity of 0.23 percentage points. On the other hand, the swap hedge ratio negatively affects the allocation to hedge funds. The results for hedge funds should, however, be interpreted with care for mainly two reasons. First, the number of uncensored observations is relatively small compared to the total number of observations. Second, events outside our model may have impacted hedge fund allocation. Some hedge funds received negative publicity during the financial crisis because investors who tried to withdraw their money to meet liquidity needs were unable to do so. This may play a role in the allocation to hedge funds.

The results for the foreign exchange hedge ratio are also mixed across the different asset classes. The foreign exchange hedge ratio does not affect the allocation to hedge funds and negatively affects the allocation to private equity. A one standard deviation increase in collateral requirement leads to an increase in the fraction of risky assets allocated to private equity of 0.80 percentage points.

The required funding ratio also has different effects. Pension funds with a higher required funding ratio invest more in private equity and less in mortgages. This reveals that pension funds with a higher tolerance for risk might prefer certain illiquid assets over others.

These differences in findings indicate that strategic decisions made at the top level do not have to be implemented at each individual asset class level. What matters is that the overall investment policy, risk exposures and liquidity profile are in accordance with the policy set by the pension fund.

\section{Robustness check}

From the previous sections, it follows that the impact of liability duration on the illiquid assets allocation is strong. As a robustness check, we take an alternative measure of liability duration in this section. Liability duration measures the maturity of a pension fund and this is directly related to demographics. Although we have no data on demographics, we do know the pension payments and the value of the liabilities per year. The ratio of pension payments to the value of the liabilities is an alternative measure for maturity (De Haan, 2018). If this ratio is high, a large part of the participants consists of retirees.

In the robustness check, we replace the liability duration by the ratio of pension payments to liabilities (Benefits). ${ }^{17}$ Table 8 shows that using this alternative measure also results in a hump-shaped impact on the fraction of risky assets allocated to illiquid assets. Up to a ratio of $4.8 \%$, the fraction of risky assets allocated to illiquid assets is positively affected. ${ }^{18}$ After this point, the effect is reversed. Column (3) of Table 8 shows that the hump-shaped effect is absent for the allocation to risky assets.

In our theoretical framework, we saw that the ratio of pension payments to the value of liabilities is given by $1 / D_{V}$ (see Equation (4) in Section 2). Figure 4 provides evidence that the fitted curve for the observed ratios of pension payments to pension liabilities is indeed a convex and decreasing function of liability duration, in line with the theoretical framework. This confirms that the inverse of the liability duration is a good proxy for the liquidity requirement from pension payments.

\section{Illiquid assets allocation in different regulatory frameworks}

Compared to banks and insurance companies, pension fund regulation is much more diverse across countries. Here, we focus on the difference in capital requirements for pension funds in the USA and Canada to show our model implications outside the Netherlands. The USA and Canada have fixed capital requirements, whereas the Netherlands has risk-based capital requirements.

\footnotetext{
${ }^{17}$ We only include observations at the end of each year as the pension payments are only available on an annual basis. The sample period is 2012-2016, as the pension payments for the year 2017 are not available yet.

$18 \frac{\partial w^{\text {ILLIQ }} / w^{\text {RISKY }}}{\partial \text { Benefits }}=\beta_{1}+2 \beta_{2}$ Benefits $=0 \rightarrow$ Benefits $=-\frac{\beta_{1}}{2 \beta_{2}}$.
} 
Table 7. Main results - separate illiquid assets classes

\begin{tabular}{|c|c|c|c|c|}
\hline Dependent variable & $w^{R E} / w^{(1)}$ & $w^{M G} / w^{R I S K Y}$ & $w^{P E} / w^{(3)}$ & $w^{H F} / w^{R I S K Y}$ \\
\hline \multirow[t]{2}{*}{$D_{V}$} & $0.0138^{\star \star \star}$ & $0.0178^{\star \star}$ & $0.0076^{\star \star}$ & $0.0753^{\star \star \star}$ \\
\hline & $(0.0045)$ & $(0.0070)$ & $(0.0036)$ & $(0.0088)$ \\
\hline \multirow{2}{*}{$D_{V}^{2}$} & $-0.0004^{\star \star *}$ & $-0.0004^{\star *}$ & $-0.0002^{\star \star \star}$ & -0.0022 \\
\hline & $(0.0001)$ & $(0.0002)$ & $(0.0001)$ & $(0.0002)$ \\
\hline \multirow[t]{2}{*}{$C R r$} & 0.0409 & -0.0453 & $0.0585^{\star}$ & $-0.1474^{\star}$ \\
\hline & $(0.0427)$ & $(0.0947)$ & $(0.0325)$ & $(0.0835)$ \\
\hline \multirow[t]{2}{*}{$C R f x$} & $0.1085^{\star \star \star}$ & $0.2535^{\star \star \star}$ & $-0.2068^{\star \star \star}$ & -0.0216 \\
\hline & $(0.0316)$ & $(0.0420)$ & $(0.0435)$ & $(0.0653)$ \\
\hline \multirow[t]{2}{*}{$\phi^{B}$} & 0.0187 & 0.0151 & $-0.0209^{\star \star}$ & $-0.0855^{\star \star \star}$ \\
\hline & $(0.0143)$ & $(0.0281)$ & $(0.0102)$ & $(0.0243)$ \\
\hline \multirow[t]{2}{*}{$w^{F X}$} & $0.0767^{\star \star \star}$ & $-0.0454^{\star \star \star}$ & 0.0041 & $0.0290^{*}$ \\
\hline & $(0.0101)$ & $(0.0172)$ & $(0.0069)$ & $(0.0164)$ \\
\hline \multirow[t]{2}{*}{ Size } & $0.0541^{\star * *}$ & $0.0510^{\star * \star}$ & $0.0608^{\star \star \star}$ & 0.0156 \\
\hline & $(0.0088)$ & $(0.0120)$ & $(0.0065)$ & $(0.0102)$ \\
\hline \multirow[t]{2}{*}{ Corp } & $-0.0544^{\star \star \star}$ & $-0.0846^{\star \star \star}$ & $-0.0218^{\star \star}$ & 0.0068 \\
\hline & $(0.0175)$ & $(0.0223)$ & $(0.0091)$ & $(0.0178)$ \\
\hline \multirow[t]{2}{*}{ Prof } & -0.0004 & -0.0620 & $0.0300^{\star}$ & $0.0937^{\star * *}$ \\
\hline & $(0.0377)$ & $(0.0444)$ & $(0.0161)$ & $(0.0330)$ \\
\hline \multirow[t]{2}{*}{$R f r$} & -0.0001 & $-0.2514^{\star \star \star}$ & $0.1340^{\star \star \star}$ & 0.0172 \\
\hline & $(0.0134)$ & $(0.0705)$ & $(0.0309)$ & $(0.0138)$ \\
\hline \multirow[t]{2}{*}{$\mathrm{Fr}$} & $-0.1206^{\star \star \star}$ & $0.1164^{\star * \star}$ & $0.0725^{\star \star \star}$ & -0.1167 \\
\hline & $(0.0220)$ & $(0.0357)$ & (0.0158) & $(0.0360)$ \\
\hline Time FE & Y & Y & $Y$ & Y \\
\hline$N$ & 3,432 & 3,432 & 3,432 & 3,432 \\
\hline Left-censored & 1,359 & 2,186 & 2,200 & 2,851 \\
\hline Uncensored & 2,073 & 1,246 & 1,232 & 581 \\
\hline
\end{tabular}

In this table, we show the random effects estimators based on the regression (15) for separate illiquid asset classes. The dependent variable in the first column is the fraction of risky assets allocated to real estate $w^{R E} / w^{R I S K Y}$, in the second column the fraction of risky assets allocated to mortgages $\left(w^{M G} / w^{R I S K Y}\right)$, in the third column the fraction of risky assets allocated to private equity ( $w^{P E} / w^{R I S K Y}$ ), and in the fourth column the fraction of risky assets allocated to hedge funds $\left(w^{H F} / w^{R I S K Y}\right)$. The independent variables include the liability duration $\left(D_{V}\right)$, the liability duration squared $\left(D_{V}^{2}\right)$, the collateral requirements on interest rate derivatives $(C R r)$, the collateral requirements on currency derivatives (CRfx), bond hedge ratio $\left(\phi^{B}\right)$, fraction of foreign investments $\left(w^{F X}\right)$, the log of total AUM (Size), Corp indicates a corporate pension fund, Prof indicates a professional pension fund, $R f r$ is the required funding ratio, and $F r$ the one period lag of the actual funding ratio. Standard errors are between parentheses; ${ }^{*} p<0.10 ;{ }^{*} p<0.05 ; p<0.01$.

Boon et al. (2018) study public, corporate, and industry-wide pension funds in the USA, Canada, and the Netherlands and find that the regulatory framework matters for the asset allocation decisions. They show that risk-based capital requirements and mark-to-market valuation are associated with a 7 percentage points lower allocation to risky assets, regardless of market conditions. Given this evidence and the setup of our model, we conjecture the following implications for the illiquid assets allocations in the USA and in Canada. A higher interest rate risk exposure does not increase the capital requirements for pension funds in the USA and Canada. Under this condition, the impact of the liability duration on the illiquid assets allocation is likely to be increasing. In other words, the higher the liability duration, the higher we expect the illiquid assets allocation to be. Therefore, we expect higher illiquid asset allocations in the USA and Canada. This is indeed what we observe empirically. The Willis Towers Watson Global Pension Assets Study (2018) shows that the value-weighted average illiquid assets allocation in the USA equals $28 \%$ and Canada equals $31 \%$, whereas in the Netherlands it is only $17 \%{ }^{19}$

The predictions of our model are likely to be amplified when considering life insurers. Life insurers have high liability durations and are subject to Solvency II regulation in Europe. Under this solvency regime, the capital requirement is calibrated on a $0.5 \% 1$-year default probability. This implies that the capital requirement is more profound for European life insurers than for Dutch pension funds, for which the capital requirement is calibrated on a $2.5 \%$ probability. We, therefore, predict the turning point of the hump-shaped effect of the liability duration on the illiquid assets allocation to be at a

${ }^{19}$ https://www.willistowerswatson.com/-/.../Global-Pension-Asset-Study-2018-Japan.pdf 
Table 8. Robustness - alternative measure of liability duration

\begin{tabular}{|c|c|c|c|}
\hline Dependent variable & $w^{I L L I Q} / w^{\text {IISKY }}$ & $\begin{array}{c}(2) \\
w^{I L L I Q}\end{array}$ & $\begin{array}{c}\text { (3) } \\
w^{R I S K Y}\end{array}$ \\
\hline Benefits & $\begin{array}{l}6.9264^{\star \star \star} \\
(1.5747)\end{array}$ & $\begin{array}{l}4.3555^{\star \star \star} \\
(1.0672)\end{array}$ & $\begin{array}{c}2.8844^{\star} \\
(1.7548)\end{array}$ \\
\hline Benefits $^{2}$ & $\begin{array}{c}-71.5539^{\star \star \star} \\
(22.1661)\end{array}$ & $\begin{array}{c}-38.0856^{\star \star} \\
(15.0461)\end{array}$ & $\begin{array}{c}12.4495 \\
(24.3063)\end{array}$ \\
\hline$C R r$ & $\begin{array}{c}0.0894 \\
(0.1408)\end{array}$ & $\begin{array}{c}0.0708 \\
(0.0964)\end{array}$ & $\begin{array}{c}-0.0512 \\
(0.1830)\end{array}$ \\
\hline$C R f x$ & $\begin{array}{c}0.1016 \\
(0.0806)\end{array}$ & $\begin{array}{c}0.0875 \\
(0.0553)\end{array}$ & $\begin{array}{l}0.3857^{\star \star \star} \\
(0.1100)\end{array}$ \\
\hline$\phi^{B}$ & $\begin{array}{r}-0.0767^{*} \\
(0.0382)\end{array}$ & $\begin{array}{l}-0.1045^{\star \star \star} \\
(0.0264)\end{array}$ & $\begin{array}{c}-0.4227^{\star \star \star \star} \\
(0.0469)\end{array}$ \\
\hline$w^{F X}$ & $\begin{array}{c}0.0342 \\
(0.0271)\end{array}$ & $\begin{array}{c}0.0090 \\
(0.0186)\end{array}$ & $\begin{array}{l}-0.1412^{\star \star \star} \\
(0.0345)\end{array}$ \\
\hline Size & $\begin{array}{l}0.0774^{\star \star \star} \\
(0.0125)\end{array}$ & $\begin{array}{l}0.0543^{\star \star \star} \\
(0.0083)\end{array}$ & $\begin{array}{l}0.0368^{\star \star \star} \\
(0.0131)\end{array}$ \\
\hline Corp & $\begin{array}{l}-0.0760^{\star \star *} \\
(0.0216)\end{array}$ & $\begin{array}{r}-0.0466 \\
(0.0142)\end{array}$ & $\begin{array}{c}0.0069 \\
(0.0227)\end{array}$ \\
\hline Prof & $\begin{array}{c}-0.0026 \\
(0.0415)\end{array}$ & $\begin{array}{c}-0.0099 \\
(0.0272)\end{array}$ & $\begin{array}{c}-0.0485 \\
(0.0431)\end{array}$ \\
\hline Rfr & $\begin{array}{l}0.2196^{\star *} \\
(0.1153)\end{array}$ & $\begin{array}{l}0.2517^{\star \star *} \\
(0.0788)\end{array}$ & $\begin{array}{l}0.6764^{\star \star \star} \\
(0.1479)\end{array}$ \\
\hline $\mathrm{Fr}$ & $\begin{array}{r}-0.0128 \\
(0.0513)\end{array}$ & $\begin{array}{r}-0.0406 \\
(0.0349)\end{array}$ & $\begin{array}{l}-0.1867^{\star \star \star} \\
(0.0576)\end{array}$ \\
\hline Time FE & $\mathrm{Y}$ & $\mathrm{Y}$ & $\mathrm{Y}$ \\
\hline$N$ & 700 & 700 & 707 \\
\hline Left-censored & 182 & 182 & $\mathrm{n} / \mathrm{a}$ \\
\hline Uncensored & 518 & 518 & $\mathrm{n} / \mathrm{a}$ \\
\hline
\end{tabular}

In this table, we show the random effects estimators based on (15) using an alternative measure for the liability duration. The dependent variable in the first column is the fraction of risky assets allocated to illiquid assets ( $\left.w^{I L L I Q} / w^{R I S K Y}\right)$, the dependent variable in the second column is the allocation to illiquid assets $\left(w^{\text {ILLIO }}\right)$ and the third column uses the risky assets allocation as dependent variable $\left(w^{\text {RISKY }}\right)$. The independent variables include the ratio of pension payments to liabilities (Benefits), the ratio of pension payments to liabilities squared (Benefits ${ }^{2}$ ), the collateral requirements on interest rate derivatives $(C R r)$, the collateral requirements on currency derivatives (CRfx), bond hedge ratio $\left(\phi^{B}\right)$, fraction of foreign investments $\left(w^{F X}\right)$, the log of total AUM (Size), Corp indicates a corporate pension fund, Prof indicates a professional pension fund, $R f r$ is the required funding ratio, and $F r$ the one-period lag of the actual funding ratio. Standard errors are between parentheses; ${ }^{*} p<0.10 ;{ }^{* *} p<0.05 ; p<0.01$.

lower liability duration for insurance companies. In other words, the negative effect of having a higher liability duration (higher capital requirements) will outweigh the benefits (lower liquidity requirements) at a faster rate.

\section{Conclusion}

In this paper, we empirically study the impact of liquidity and capital requirements on a pension fund's illiquid assets allocation. Liquidity requirements result from short-term pension payments and collateral requirements on derivatives used for hedging purposes. In addition, the pension funds in our sample are capital constrained. Liquidity and capital requirements interact. By hedging interest rate risk and currency risk, a pension fund is less exposed to these two risk factors and can take additional investment risks. However, hedging strategies using derivatives involve margining. This hampers a pension fund to invest in illiquid assets as they impose a liquidity requirement.

The key conclusions of our empirical analysis are as follows. First, we find a hump-shaped impact of liability duration on the fraction of risky assets allocated to illiquid assets. Up to 18 years, the liability duration positively affects this allocation. However, beyond this point, the effect is reversed and the allocation to illiquid assets decreases. Second, we do not find evidence that swap hedge ratios impact the illiquid assets allocation: the liquidity and capital requirements cancel each other out. In the case of currency risk, however, hedging does impact the illiquid assets allocation positively. Finally, pension fund size, pension fund type, and funding ratio also impact the illiquid assets allocation. 


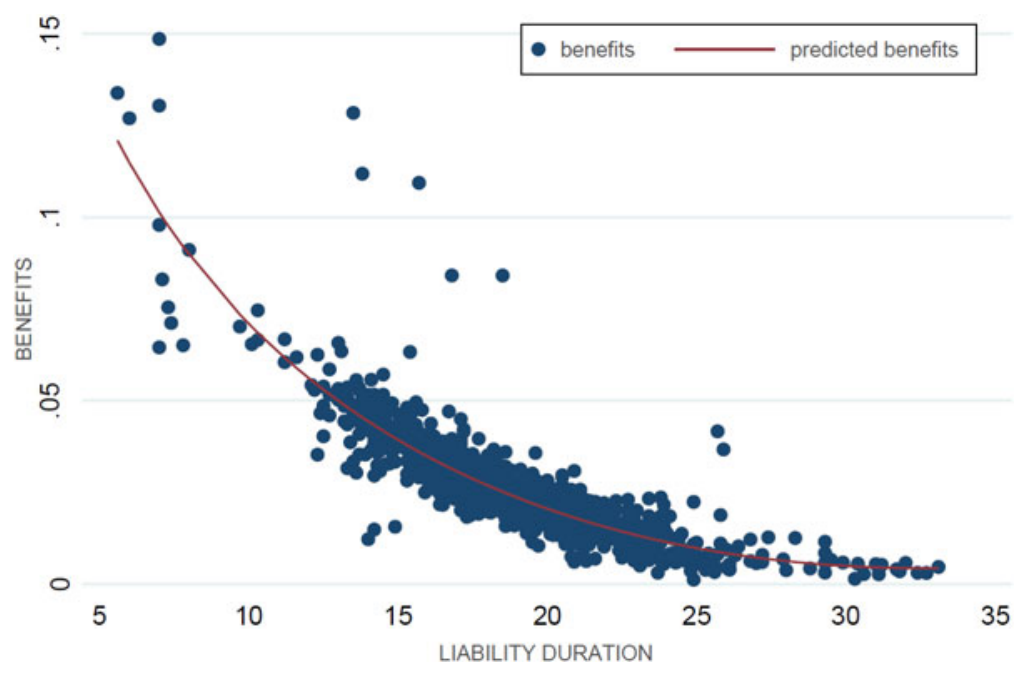

Figure 4. Benefits as a function of the liability duration. The dots in this figure show the observed ratios of pension payments to pension liabilities (Benefits) and the fitted curve for the observed ratios of pension payments to pension liabilities (red line), both as a function of the liability duration.

These findings offer important policy implications. Based on our model and empirical findings it does not appear obvious for long-term investors to always invest more in illiquid assets. The capital requirement for defined benefit pension funds becomes a binding constraint if the liability duration is substantially high. Although relaxing capital requirements for interest rate risk might seem a reasonable solution to mitigate the impact of this constraint, this is not what we recommend. The interest rate risk is inherent to the nature of the pension liabilities in a defined benefit pension contract. If a pension fund guarantees benefits, interest rate risk becomes the key risk factors to manage. An alternative approach would be to redefine pension liabilities such that they no longer embed long-term interest rate guarantees. This, however, means that the interest rate risk shifts to the beneficiaries. Beneficiaries are less knowledgeable to understand and less equipped to manage interest rate risk.

A more important policy implication concerns adequate liquidity and collateral management for pension funds. Pension funds increasingly use derivatives to hedge risks. Derivatives involve greater liquidity needs. These liquidity needs can increase exponentially in times of market turbulence. Collateral management is therefore key and becomes even greater once pension funds are integrated into the central clearing of derivatives. Pension funds should prepare adequate contingency planning to be able to manage collateral through periods of market turbulence. More emphasis could, therefore, be placed on liquidity and collateral management in pension regulations.

Acknowledgement. We thank two anonymous referees, editor Stephen Dimmock, Jules van Binsbergen, Bart Bos, Lisanne Cock, Pieter van Foreest, Rob van den Goorbergh, Janko Gorter, Leo de Haan, Frank de Jong, Theo Nijman, Arco van Oord, Marco Teunissen, Marno Verbeek, Manon ten Voorde, Sweder van Wijnbergen, participants of seminars at Achmea Investment Management, APG, Basel University, Cardano, DNB, EPFIF, Fidelity, ICPM, Maastricht University, Ortec Finance, Robeco and conference participants of the INPARR Seminar Consistency Amid Complexity: Navigating the Future of Pensions (OECD, Paris) and the International Pension Workshop (Netspar, Leiden) for very useful comments. Moreover, we are grateful to David Keijzer and Jeroen Meringa for the data gathering process. Kristy gratefully acknowledges financial support from Instituut Gak.

\section{References}

Alestalo N and Puttonen V (2006) Asset allocation in Finnish pension funds. Journal of Pension Economics and Finance 5, $27-44$ 
An H, Huang Z and Zhang T (2013) What determines corporate pension fund risk-taking strategy? Journal of Banking and Finance 37, 597-613.

Andonov A (2014) Delegated investment management in alternative assets. Netspar Discussion Paper No. 03/2014-085.

Andonov A, Bauer R and Cremers M (2017) Pension fund asset allocation and liability discount rates. Review of Financial Studies 30, 2555-2595.

Ang A, Papanikolaou D and Westerfield M (2014) Portfolio choice with illiquid assets. Management Science 60, $2737-2761$.

Attig N, Cleary S, El Ghoul S and Guedhami O (2012) Institutional investment horizon and investment cash flow sensitivity. Journal of Banking \& Finance 36, 1164-1180.

Basak S and Shapiro A (2001) Value-at-risk-based risk management: optimal policies and asset prices. Review of Financial Studies 14, 371-405.

Bikker J, Broeders D and de Dreu J (2010) Stock market performance and pension fund investment policy: rebalancing, free float, or market timing? International Journal of Central Banking 6, 53-79.

Binsbergen J, Brandt M and Koijen R (2008) Optimal decentralized investment management. Journal of Finance 63, 18491895.

Boon L, Brière M and Rigot S (2018) Regulation and pension fund risk taking. Journal of International Money and Finance 84, 23-41.

Boubaker S, Gounopoulos D, Nguyen D and Paltalidis N (2017) Assessing the effects of unconventional monetary policy and low interest rates on pension fund risk incentives. Journal of Banking \& Finance 77, 35-52.

Broeders D (2010) Valuation of contingent pension liabilities and guarantees under sponsor default risk. Journal of Risk and Insurance 77, 911-934.

Broeders D and Pröpper M (2010) Risk-based supervision of pension funds in the Netherlands. In Micocci M, Gregoriou GN and Masala GB (eds), Pension Fund Risk Management: Financial and Actuarial Modeling. London: Chapman \& Hall.

Broeders D, Oord A and Rijsbergen D (2016) Scale economies in pension fund investments: a dissection of investment costs across asset classes. Journal of International Money and Finance 67, 147-171.

De Haan L (2018) Recovery measures of underfunded pension funds: higher contributions, no indexation, or pension cuts? Journal of Pension Economics and Finance 17, 437-468.

Dyck A and Pomorski L (2016) Investor scale and performance in private equity investments. Review of Finance 20, 1081-1106.

Franzoni F, Nowak E and Phalippou L (2012) Private equity performance and liquidity risk. Journal of Finance 67, 23412373.

Gârleanu N (2009) Portfolio choice and pricing in illiquid markets. Journal of Economic Theory 144, 532-564.

Hansen K (1998) Seasonality of moves and duration of residence. Technical report, Bureau of Census, U.S. Department of Commerce.

Hoevenaars R, Molenaar R, Schotman P and Steenkamp T (2008) Strategic asset allocation with liabilities: beyond stocks and bonds. Journal of Economic Dynamics and Control 32, 2939-2970.

Jacobs H, Müller S and Weber M (2014) How should individual investors diversify? An empirical evaluation of alternative asset allocation policies. Journal of Financial Markets 19, 62-85.

Jin L, Merton R and Bodie Z (2006) Do a firm's equity returns reflect the risk of its pension plans? Journal of Financial Economics 81, 1-26.

Khan M, Scheule H and Wu E (2017) Funding liquidity and bank risk taking. Journal of Banking \& Finance 82, $203-216$.

Metrick A and Yasuda A (2010) The economics of private equity funds. Review of Financial Studies 23, $2303-2341$.

Miller N, Peng L and Sklarz M (2011) The economic impact of anticipated house price changes - evidence from home sales. Real Estate Economics 39, 345-378.

Niedrig T (2015) Optimal asset allocation for interconnected life insurers in the low interest rate environment under solvency regulation. Journal of Insurance Issues 38, 31-71.

Peng J and Wang Q (2019) Alternative investments: is it a solution to the funding shortage of us public pension plans? Journal of Pension Economics and Finance. forthcoming, 1-20. doi: 10.1017/S147474721900012X.

Qian W and Liu P (2012) Does (and what) illiquidity matter for real estate prices? Measure and evidence. SSRN Electronic Journal. doi: 10.2139/ssrn.1988837.

Rauh J (2009) Risk shifting versus risk management: investment policy in corporate pension plans. Review of Financial Studies 22, 2687-2733.

Sadka R (2010) Liquidity risk and the cross-section of hedge-fund returns. Journal of Financial Economics 98, 54-71.

Sharpe W (1976) Corporate pension funding policy. Journal of Financial Economics 3, 183-193.

Sias R (2004) Institutional herding. Review of Financial Studies 17, 165-206.

Stoughton N and Zechner J (2011) Intermediated investment management. The Journal of Finance 66, 779-805.

Cite this article: Broeders DWGA, Jansen KAE, Werker BJM (2021). Pension fund's illiquid assets allocation under liquidity and capital requirements. Journal of Pension Economics and Finance 20, 102-124. https://doi.org/10.1017/ S1474747219000398 